\title{
Real-Life Evidence for Tedizolid Phosphate in the Treatment of Cellulitis and Wound Infections: A Case Series
}

\author{
Sergey Shlyapnikov • Arturo Jauregui · Nana N. Khachatryan • \\ Asok Kurup · Javier de la Cabada-Bauche · Hoe N. Leong • \\ Li Li · Mark H. Wilcox
}

Received: March 19, 2018 / Published online: July 12, 2018

(C) The Author(s) 2018

\begin{abstract}
Introduction: Tedizolid phosphate $200 \mathrm{mg}$, once daily for 6 days, has recently been approved for the treatment of patients with acute bacterial skin and skin structure infections (ABSSSIs) in several countries; however, clinical experience in real-life settings is currently limited. Here, we report on the use of tedizolid with an extended treatment duration for complex and severe ABSSSIs in real-world clinical settings.

Methods: Two patients with cellulitis and two patients with surgical site infection (SSI), aged 26-60 years, were treated with tedizolid phosphate $200 \mathrm{mg}$, intravenous/oral (IV/PO) or IV only, once daily at four different institutions.
\end{abstract}

Enhanced digital features To view enhanced digital features for this article go to https://doi.org/10.6084/ m9.figshare.6729146.

S. Shlyapnikov

Science Research Institute of Emergency Care of

Saint Petersburg, Saint Petersburg, Russia

\section{A. Jauregui}

Department of Infectious Diseases, Hospital Angeles Chihuahua, Chihuahua, Mexico

N. N. Khachatryan

Moscow State Medical Stomatology University,

Moscow, Russia

A. Kurup

Mount Elizabeth Medical Centre, Mount Elizabeth

Hospital, Singapore, Singapore
Results: Two morbidly obese patients had nonnecrotizing, non-purulent severe cellulitis, which were complicated by sepsis or systemic inflammatory response syndrome plus myositis. One female patient failed on first-line empiric therapy with IV cefalotin, clindamycin and imipenem (3-4 days), and was switched to IV/ PO tedizolid $(7+5$ days $)$. One male patient received IV clindamycin plus IV/PO tedizolid $(5+5$ days $)$, but clindamycin was discontinued on Day 3 due to an adverse event. For both patients, clinical signs and symptoms improved within $72 \mathrm{~h}$, and laboratory results were normalized by Days 7 and 8 , respectively. Two other patients (one obese, diabetic female with chronic hepatitis and chronic obstructive pulmonary disease) had complicated SSIs occurring 10 days after hernia repair with mesh or 3 months after spinal fusion surgery with metal implant. First patient with previous methicillin-

\section{J. de la Cabada-Bauche}

Department of Infectious Diseases, Hospital San Javier, Guadalajara, Mexico

H. N. Leong

Rophi Clinic Pte Ltd, Mount Elizabeth Novena Specialist Centre, Singapore, Singapore

L. Li

Bayer AG, Berlin, Germany

M. H. Wilcox $(\bowtie)$

Department of Microbiology, Leeds Teaching

Hospitals NHS Trust, University of Leeds, Leeds, UK e-mail: mark.wilcox@nhs.net 
resistant Staphylococcus aureus (MRSA) bacteremia received a 7-day tedizolid IV course empirically. The second patient with cultureconfirmed MRSA infection received a 14-day IV course. Both patients responded within $72 \mathrm{~h}$, and local and systemic signs normalized by end of treatment. There were no reports of thrombocytopenia.

Conclusion: Tedizolid phosphate $200 \mathrm{mg}$ for 7-14 days was a favored treatment option for patients with severe/complex ABSSSIs, and was effective following previous treatment failure or in late-onset infections.

Funding: Editorial assistance and the article processing charges were funded by Bayer AG, Berlin, Germany.

Keywords: Extended treatment duration; MRSA; Real-life evidence; Severe cellulitis; Severe surgical wound infection; Tedizolid phosphate

\section{INTRODUCTION}

Acute bacterial skin and skin structure infections (ABSSSIs; i.e. cellulitis, erysipelas, wound infection and major cutaneous abscess) are the most frequently diagnosed clinical presentations of skin infections in the USA, Europe, Asia and Russia [1-6], and present a huge burden on healthcare systems [3], particularly when patients have multiple comorbidities [6] and/or complications [7].

Tedizolid phosphate is a novel oxazolidinone antibiotic, which is rapidly converted in vivo to tedizolid, the active moiety, by nonspecific phosphatases $[8,9]$. Tedizolid has high in vitro activity against a range of Gram-positive bacteria, including Streptococcus pyogenes, vancomycin-resistant enterococci and methicillinresistant Staphylococcus aureus (MRSA) [10, 11]. Tedizolid phosphate $200 \mathrm{mg}$ is available in intravenous (IV) and oral (PO) formulations, and has a high oral bioavailability (82-95\%), a convenient dosing regimen (once daily, irrespective of food) and a relatively short duration of therapy (6 days) $[8,9,12-14]$. In two randomized, double-blind, multicenter Phase 3 studies in patients with ABSSSIs, 6 days of treatment with tedizolid phosphate $200 \mathrm{mg} \mathrm{IV} /$ PO once daily was non-inferior to 10 days of treatment with linezolid $600 \mathrm{mg}$ IV/PO twice daily [15-17]. Tedizolid phosphate was approved for use in 2014 by the US Food and Drug Administration and in 2015 by the European Medicines Agency, and is now also available for the treatment of ABSSSIs in several countries outside the USA and Europe, including Mexico and Singapore [18, 19], and for the treatment of complicated skin and skin structure infections (cSSSIs) in Russia [20].

We report here the real-world experiences of using tedizolid phosphate in patients with complex ABSSSIs/cSSSIs, who would generally not be included in typical Phase 3 clinical trials because of the complex nature and severity of their infections, and the likelihood of their failure to meet trial inclusion criteria. We believe that these cases extend knowledge on the efficacy and tolerability of tedizolid phosphate in the real-life treatment of complex and severe ABSSSIs/cSSSIs, including the use of therapeutic courses longer than the 6 days used in Phase 3 studies.

\section{CASE PRESENTATIONS}

Four patients with complex cases of ABSSSI were treated with tedizolid phosphate $200 \mathrm{mg}$, once daily (Table 1). Informed consent was obtained by the treating physicians from each patient for being included in the publication.

\section{Case 1}

A 46-year-old, morbidly obese [body mass index (BMI): $46.1 \mathrm{~kg} / \mathrm{m}^{2}$ ] woman developed contact dermatitis due to second-degree burns. She had bullae with clear fluid at the burn sites (Fig. 1a) and developed rapid-onset cellulitis, which was painful, erythematous and swollen (Fig. 1a). Necrotizing infection was ruled out by imaging (i.e., computed tomography scan, Doppler ultrasound).

After presenting to her local hospital, she was diagnosed with a non-purulent, nonnecrotizing, severe cellulitis, complicated by hypovolemia and sepsis. Blood cultures proved 
Table 1 Overview of cases

\begin{tabular}{|c|c|c|c|c|}
\hline & Case 1 & Case 2 & Case 3 & Case 4 \\
\hline $\begin{array}{l}\text { Age } \\
\text { (years)/gender }\end{array}$ & 46/female & $38 /$ male & $60 /$ female & $26 /$ male \\
\hline Diagnosis & $\begin{array}{l}\text { Non-purulent, non- } \\
\text { necrotizing, severe } \\
\text { cellulitis on lower } \\
\text { extremity of right leg, } \\
\text { complicated by } \\
\text { hypovolemia and } \\
\text { sepsis }\end{array}$ & $\begin{array}{l}\text { Non-purulent, non- } \\
\text { necrotizing, severe } \\
\text { cellulitis on lower } \\
\text { extremity of right leg, } \\
\text { complicated by SIRS } \\
\text { and myositis }\end{array}$ & $\begin{array}{l}\text { Acute erythematous } \\
\text { surgical wound } \\
\text { infection }\end{array}$ & $\begin{array}{l}\text { Erythematous, purulent } \\
\text { surgical wound } \\
\text { infection }\end{array}$ \\
\hline \multirow{7}{*}{$\begin{array}{l}\text { Laboratory } \\
\text { results at the } \\
\text { time of } \\
\text { initiating } \\
\text { tedizolid } \\
\text { treatment }\end{array}$} & $\begin{array}{l}\text { Elevated white blood } \\
\text { cell count }\end{array}$ & $\begin{array}{l}\text { Elevated white blood } \\
\text { cell count }\end{array}$ & $\begin{array}{l}\text { Elevated white blood cell } \\
\text { count }\end{array}$ & $\begin{array}{l}\text { Elevated white blood cell } \\
\text { count }\end{array}$ \\
\hline & $\begin{array}{l}\text { Elevated immature } \\
\text { neutrophil bands } \\
\text { Elevated blood urea } \\
\text { nitrogen }\end{array}$ & $\begin{array}{l}\text { Elevated C-reactive } \\
\text { protein level } \\
\text { Elevated serum } \\
\text { creatinine level }\end{array}$ & $\begin{array}{l}\text { Elevated immature } \\
\text { neutrophil bands } \\
\text { Elevated hepatic enzyme } \\
\text { levels }\end{array}$ & $\begin{array}{l}\text { Elevated immature } \\
\text { neutrophil bands }\end{array}$ \\
\hline & $\begin{array}{l}\text { Elevated serum } \\
\text { creatinine level }\end{array}$ & $\begin{array}{l}\text { Elevated creatine kinase } \\
\text { level }\end{array}$ & $\begin{array}{l}\text { Elevated blood urea } \\
\text { nitrogen }\end{array}$ & \\
\hline & $\begin{array}{l}\text { Platelet count }\left(\times 10^{9} /\right. \\
\text { L) changes: }\end{array}$ & $\begin{array}{l}\text { Platelet count }\left(\times 10^{9} /\right. \\
\text { L) changes: }\end{array}$ & $\begin{array}{l}\text { Platelet count }\left(\times 10^{9} /\right. \\
\text { L) changes: }\end{array}$ & $\begin{array}{l}\text { Platelet count }\left(\times 10^{9} /\right. \\
\text { L) changes: }\end{array}$ \\
\hline & Before treatment: 192 & Before treatment: 230 & Before treatment: 296 & Before treatment: 235 \\
\hline & $\begin{array}{l}\text { During IV treatment: } \\
254\end{array}$ & $\begin{array}{l}\text { During IV treatment: } \\
200\end{array}$ & $\begin{array}{l}\text { During IV treatment: } \\
320\end{array}$ & $\begin{array}{l}\text { During IV treatment: } \\
260\end{array}$ \\
\hline & At IV/PO switch: 299 & At IV/PO switch: 230 & After IV treatment: 324 & After IV treatment: 240 \\
\hline $\begin{array}{l}\text { Microbiology } \\
\text { testing }\end{array}$ & $\begin{array}{l}\text { Negative blood culture; } \\
\text { no sample was taken } \\
\text { from primary ABSSSI } \\
\text { site }\end{array}$ & $\begin{array}{l}\text { Negative blood culture; } \\
\text { no sample was taken } \\
\text { from primary } \\
\text { ABSSSI site }\end{array}$ & $\begin{array}{l}\text { Hemorrhagic fluid from } \\
\text { wound was collected } \\
\text { for culture and MRSA } \\
\text { was confirmed } \\
\text { MRSA was reported to } \\
\text { be susceptible to } \\
\text { vancomycin, } \\
\text { daptomycin, linezolid, } \\
\text { rifampicin, fusidic acid, } \\
\text { and resistant to } \\
\text { oxacillin, cefoxitin, } \\
\text { ceftriaxone, ceftaroline, } \\
\text { ciprofloxacin }\end{array}$ & $\begin{array}{l}\text { Purulent exudate from } \\
\text { wound was collected } \\
\text { for culture and MRSA } \\
\text { was confirmed, with } \\
\text { elevated vancomycin } \\
\text { MIC }=2 \mu \mathrm{g} / \mathrm{mL} \\
\text { MRSA was reported to } \\
\text { be susceptible to } \\
\text { vancomycin, linezolid; } \\
\text { no information is } \\
\text { available on } \\
\text { daptomycin, } \\
\text { ceftaroline, or } \\
\text { rifampicin }\end{array}$ \\
\hline
\end{tabular}


Table 1 continued

\begin{tabular}{|c|c|c|c|c|}
\hline & Case 1 & Case 2 & Case 3 & Case 4 \\
\hline Medical history & $\begin{array}{l}\text { Obesity (BMI: } 46.1 \mathrm{~kg} / \\
\mathrm{m}^{2} \text { ) }\end{array}$ & $\begin{array}{l}\text { Obesity (BMI: } 59.4 \mathrm{~kg} / \\
\left.\mathrm{m}^{2}\right) \text {, tinea pedis and } \\
\text { obstructive sleep } \\
\text { apnea }\end{array}$ & $\begin{array}{l}\text { Obesity (BMI: } 34.0 \mathrm{~kg} / \\
\mathrm{m}^{2} \text { ), type } 2 \text { diabetes } \\
\text { mellitus, COPD, } \\
\text { hepatitis, renal } \\
\text { impairment } \\
\text { Previous surgery for } \\
\text { acute necrotizing } \\
\text { pancreatitis; MRSA } \\
\text { bacteremia }\end{array}$ & None \\
\hline $\begin{array}{l}\text { Prior antibiotics } \\
\text { (if any) }\end{array}$ & $\begin{array}{l}\text { First-generation } \\
\text { cephalosporin, } \\
\text { clindamycin and } \\
\text { imipenem }\end{array}$ & None & Vancomycin & None \\
\hline $\begin{array}{l}\text { Form of } \\
\text { treatment }\end{array}$ & $\begin{array}{l}\text { Tedizolid phosphate } \\
200 \mathrm{mg} \text { IV, QD, } \\
7 \text { days }+200 \mathrm{mg} \text { PO, } \\
\text { QD, } 5 \text { days }\end{array}$ & $\begin{array}{l}\text { Tedizolid phosphate } \\
200 \mathrm{mg} \text { IV, QD, } \\
5 \text { days }+200 \mathrm{mg} \\
\text { PO, QD, } 5 \text { days }\end{array}$ & $\begin{array}{l}\text { Tedizolid phosphate } \\
200 \mathrm{mg} \text { IV, QD, } \\
7 \text { days }\end{array}$ & $\begin{array}{l}\text { Tedizolid phosphate } \\
200 \text { mg IV, QD, } \\
14 \text { days }\end{array}$ \\
\hline $\begin{array}{l}\text { Reason for } \\
\text { using } \\
\text { tedizolid }\end{array}$ & $\begin{array}{l}\text { Presence of morbid } \\
\text { obesity, presence of } \\
\text { rapidly spreading } \\
\text { cellulitis after lack of } \\
\text { response to initial } \\
\text { empiric therapy and } \\
\text { reduction in platelet } \\
\text { count, and high risk } \\
\text { of MRSA; tedizolid } \\
\text { has greater potency } \\
\text { than linezolid against } \\
\text { MRSA }\end{array}$ & $\begin{array}{l}\text { Presence of morbid } \\
\text { obesity and } \\
\text { comorbidities, } \\
\text { patient expressed } \\
\text { preference for once- } \\
\text { daily therapy with } \\
\text { ongoing GI } \\
\text { symptoms, and high } \\
\text { risk of MRSA; } \\
\text { tedizolid has greater } \\
\text { potency than } \\
\text { linezolid against } \\
\text { MRSA }\end{array}$ & $\begin{array}{l}\text { Presence of obesity, } \\
\text { comorbidities, } \\
\text { ongoing renal and } \\
\text { hepatic abnormalities, } \\
\text { and previous } \\
\text { vancomycin treatment } \\
\text { and MRSA bacteremia }\end{array}$ & $\begin{array}{l}\text { Elevated vancomycin } \\
\text { MIC of confirmed } \\
\text { MRSA, extended } \\
\text { duration of treatment } \\
\text { (e.g., weeks) was } \\
\text { anticipated }\end{array}$ \\
\hline $\begin{array}{l}\text { Concomitant } \\
\text { antibiotics }\end{array}$ & None & Clindamycin & None & None \\
\hline $\begin{array}{l}\text { Any adverse } \\
\text { event }\end{array}$ & None reported & $\begin{array}{l}\text { Rash (imputed to } \\
\text { clindamycin) }\end{array}$ & None reported & None reported \\
\hline
\end{tabular}


Table 1 continued

\begin{tabular}{|c|c|c|c|c|}
\hline & Case 1 & Case 2 & Case 3 & Case 4 \\
\hline Outcome & $\begin{array}{l}\text { Cessation of lesion } \\
\text { spread within } \\
2-3 \text { days; laboratory } \\
\text { results normal or } \\
\text { improved by Day } 7\end{array}$ & $\begin{array}{l}\text { Cessation of lesion } \\
\text { spread and reduced } \\
\text { pain by Days 2-3; } \\
\text { laboratory } \\
\text { parameters improved } \\
\text { by Day } 8\end{array}$ & $\begin{array}{l}\text { Reduction in erythema } \\
\text { by Days 2-3; no } \\
\text { edema, erythema or } \\
\text { induration by end of } \\
\text { therapy }\end{array}$ & $\begin{array}{l}\text { Improved signs and } \\
\text { symptoms within } \\
2-3 \text { days, with } \\
\text { systemic signs } \\
\text { appearing normal at } \\
\text { end of therapy. } \\
\text { Wound was healed } \\
5 \text { weeks later }\end{array}$ \\
\hline
\end{tabular}

ABSSSI acute bacterial skin and skin structure infections, $B M I$ body mass index, COPD chronic obstructive pulmonary disease, GI gastrointestinal, $I V$ intravenous, MIC minimum inhibitory concentration, MRSA methicillin-resistant Staphylococcus aureus, $P O$ oral, $Q D$ once daily, SIRS systemic inflammatory response syndrome

to be negative; no specimens were taken from the primary ABSSSI site.

The patient was hospitalized and, on admission, was found to have an elevated white blood cell $(\mathrm{WBC})$ count $\left(12.2 \times 10^{9} / \mathrm{L}\right)$. Empiric treatment comprised a first-generation cephalosporin (i.e., cefalotin), clindamycin and imipenem, all administered IV. The patient showed no signs of improvement during empiric treatment and the WBC count increased progressively, reaching $41.3 \times 10^{9} / \mathrm{L}$ within 3 days, with corresponding serum levels of creatinine, blood urea nitrogen $(\mathrm{BUN})$ and procalcitonin of $1.2 \mathrm{mg} / \mathrm{dL}, 98.0 \mathrm{mg} / \mathrm{dL}$ and $1.3 \mathrm{ng} / \mathrm{mL}$, respectively. Due to the lack of response to empiric therapy, the rapidly spreading cellulitis and the high local endemicity of MRSA $(\sim 50 \%)$, the antibiotic regimen was changed to tedizolid phosphate $200 \mathrm{mg}$ IV once daily for 7 days while the patient remained in hospital. She responded to therapy, with cessation of lesion spread within $72 \mathrm{~h}$ and normalization/improvement of laboratory results by Day 5 of IV tedizolid treatment (WBC: $20.5 \times 10^{9} / \mathrm{L}$; serum creatinine: $0.6 \mathrm{mg} /$ $\mathrm{dL}$, serum BUN: $43.0 \mathrm{mg} / \mathrm{dL}$, procalcitonin: $0.2 \mathrm{ng} / \mathrm{mL}$ ). Following IV treatment, the patient was discharged and, due to the severity of the primary infection, was treated for a further 5 days with tedizolid phosphate $200 \mathrm{mg}$ PO once daily. After 2 weeks of follow-up, skin lesions had healed. No adverse event occurred and the platelet count improved with tedizolid treatment following the initial decrease (Table 1).

\section{Case 2}

A 38-year-old man presented with rapidly expanding, painful, erythematous non-purulent cellulitis on the lower extremity of his right leg. He had a very high fever [body temperature (BT): $39.4{ }^{\circ} \mathrm{C}$ ], tachycardia (110 beats/min) and relatively low blood pressure $(105 / 60 \mathrm{mmHg})$, consistent with systemic inflammatory response syndrome (SIRS), and accompanied by nausea, vomiting and diarrhea. No crepitus was observed. His medical history included tinea pedis and obstructive sleep apnea secondary to morbid obesity (BMI: $59.4 \mathrm{~kg} / \mathrm{m}^{2}$ ).

Non-necrotizing, severe cellulitis was diagnosed, complicated by myositis. No specimen was taken from the primary ABSSSI site, due to the lack of purulence, and blood cultures were negative. Laboratory test results confirmed systemic infection with acute renal impairment and muscle involvement: WBC count $18.0 \times 10^{9} / \mathrm{L}$, C-reactive protein (CRP) $285 \mathrm{mg} /$ $\mathrm{dL}$, serum creatinine $1.5 \mathrm{mg} / \mathrm{dL}$ and creatine kinase (CK): $624 \mathrm{U} / \mathrm{L}$. Due to a high suspicion of beta-hemolytic streptococci and the risk of community-acquired MRSA (the patient had recently travelled to Australasia), the patient was treated empirically with tedizolid phosphate $200 \mathrm{mg}$ IV once daily for 5 days, followed 

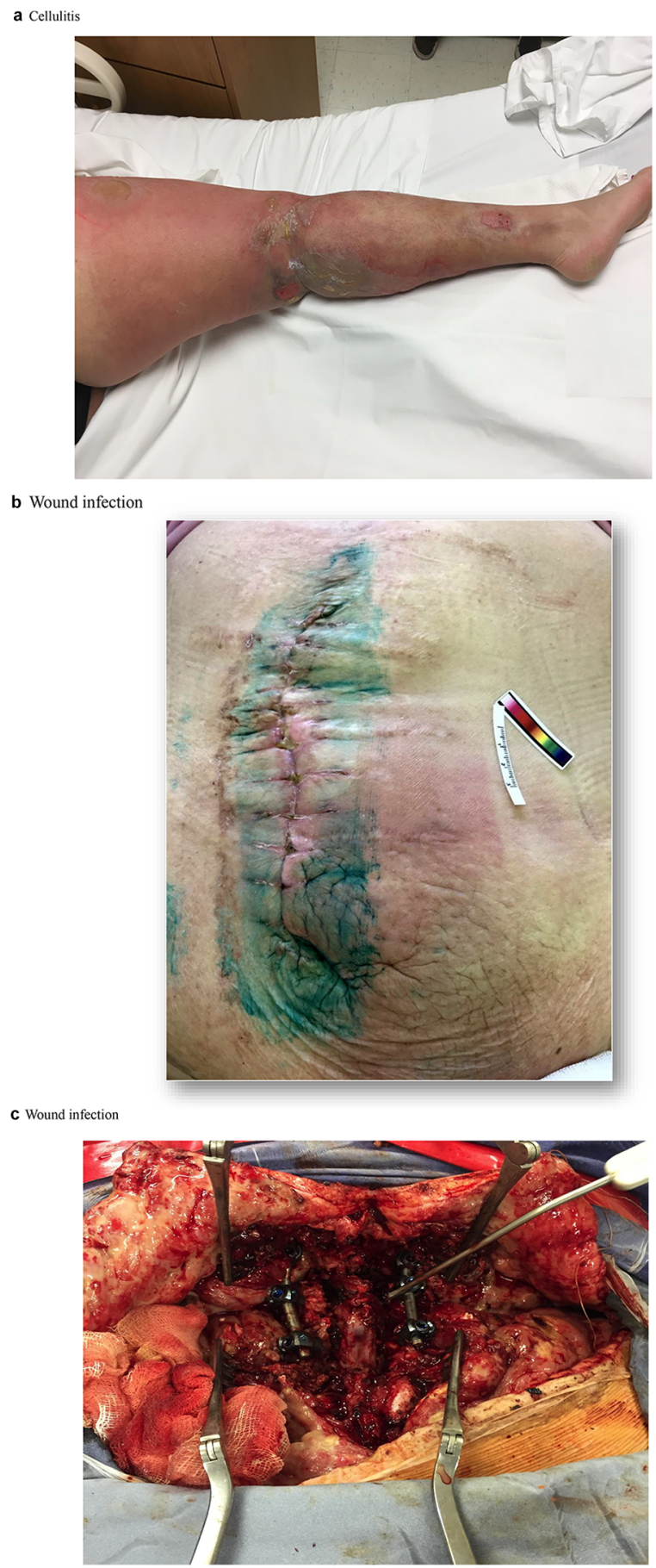

Fig. 1 Presentation of cellulitis in Case 1 (a), and wound infection in Case 2 (b) and Case 3 (c)

by tedizolid PO for 5 more days as an outpatient. Clindamycin $900 \mathrm{mg}$, q8h, was also prescribed but discontinued due to an adverse event (rash on Day 3). The patient responded within $72 \mathrm{~h}$ of antibiotic therapy, with cessation of lesion spread and a reduction in pain. Laboratory parameters, including WBC count, CRP, serum creatinine and CK levels, improved markedly, and were almost within normal limits by Day 8 (WBC count: $10.0 \times 10^{9} / \mathrm{L}$; CRP: $12 \mathrm{mg} / \mathrm{dL}$; serum creatinine: $1.0 \mathrm{mg} / \mathrm{dL}$; CK: normal). The patient remained well and was discharged after 2 weeks of outpatient followup. No adverse event occurred and the platelet count remained within the normal range during tedizolid treatment (Table 1).

\section{Case 3}

A 60-year-old woman, who underwent an elective hernia repair with mesh placement, developed a surgical site infection on Day 10 postsurgery (Fig. 1b). The patient had received thromboprophylaxis with enoxaparin $40 \mathrm{mg}$ subcutaneously once daily for 7 days following surgery. She had multiple comorbidities, including obesity (BMI: $34.0 \mathrm{~kg} / \mathrm{m}^{2}$ ), type 2 diabetes mellitus controlled by metformin, chronic obstructive pulmonary disease, chronic hepatitis, and mild renal impairment. The patient had previously been hospitalized with acute necrotizing pancreatitis (for which she underwent omentobursostomia), complicated by MRSA bloodstream infection, which was treated with vancomycin. Her acute, erythematous wound infection at presentation showed edema and induration and was accompanied by pain and a slight elevation of BT but she remained subfebrile.

Laboratory results revealed systemic inflammation (WBC count: $18.0 \times 10^{9} / \mathrm{L}$; immature neutrophil bands: 29\%), but not SIRS, elevated hepatic enzyme levels (alanine aminotransferase, aspartate aminotransferase, bilirubin) attributed to ongoing hepatitis, and mildly elevated BUN level $(18.8 \mathrm{mg} / \mathrm{dL})$. Surgical debridement was performed on the day of diagnosis, with drainage of $\sim 300 \mathrm{~mL}$ of hemorrhagic opaque fluid, a sample of which was sent for culture.

Given the presence of MRSA risk factors (i.e., previous MRSA bacteremia, previous hospitalization), comorbidities, ongoing renal impairment and previous vancomycin treatment, the 
decision was taken to treat the patient empirically with tedizolid phosphate $200 \mathrm{mg}$ IV once daily. She responded to therapy, with a decrease in erythema by Days 2-3 and a normalization of WBC count $\left(9.0 \times 10^{9} / \mathrm{L}\right)$ and immature neutrophil bands (10\%), at which point the wound fluid was reported as culture positive for MRSA. After 7 days of tedizolid phosphate therapy, edema, erythema and induration had resolved and renal laboratory parameters were normal. There was no adverse event reported and no thrombocytopenia was reported (Table 1).

\section{Case 4}

A 26-year-old previously healthy male had a serious motorbike accident, resulting in fractures to L5-S1 vertebrae that required immediate posterior spinal fusion surgery. Three months following this surgery, he re-presented with a painful, erythematous, purulent infection of the spinal wound. Fever (BT: $39.3^{\circ} \mathrm{C}$ ), elevated WBC count $\left(16.5 \times 10^{9} / \mathrm{L}\right)$ and high immature neutrophil bands (17\%) were markers and signs of systemic inflammation. The patient was diagnosed as having a deep incisional surgical wound infection. There was no definitive clinical or radiological evidence of concurrent osteomyelitis, although this was considered.

Culture and susceptibility testing of a sample of the purulent exudate yielded MRSA with an elevated vancomycin minimum inhibitory concentration (MIC) of $2 \mu \mathrm{g} / \mathrm{mL}$. Vancomycin MIC was obtained by VITEK-2 automated testing method which was confirmed by $E$ test, and this MRSA isolate was reported by the microbiologist as susceptible to vancomycin and linezolid.

The wound was debrided (Fig. 1c) and closed using vacuum assistance, and the patient was treated with tedizolid phosphate $200 \mathrm{mg}$ IV once daily for 14 days. Signs and symptoms improved (BT: $37.3^{\circ} \mathrm{C}$; WBC: $12.5 \times 10^{9} / \mathrm{L}$; immature neutrophil bands: $12 \%$ ) within $2-3$ days. By the end of therapy (Day 15), all systemic signs of infection had resolved (BT: $36.3^{\circ} \mathrm{C}$; WBC: $6.3 \times 10^{9} / \mathrm{L}$; immature neutrophil bands: $4 \%$ ) and antibiotic therapy was stopped. The wound healed completely by
Week 5. Tedizolid was well tolerated and no thrombocytopenia was reported (Table 1).

\section{DISCUSSION}

This case series describes how extended therapy with tedizolid phosphate was successful in treating severe cellulitis/myositis and wound infections in patients with complex conditions.

Cellulitis is a very common ABSSSI diagnosis, accounting for between $45 \%$ and $80 \%$ of hospitalized ABSSSI/cSSSI cases globally $[1,3]$. In the UK, over $65 \%$ of cellulitis cases are severe and require hospitalization for IV antibiotics [4], with the majority (i.e., 90\%) occurring on the lower extremities [4, 5], as in the cases reported here. A microbiological diagnosis is frequently not achieved for cellulitis, particularly in non-purulent presentations, and coverage mainly for Streptococcus pyogenes, and possibly $S$. aureus (including MRSA in endemic settings), is necessary, as these are the most common causes of such infections [21]. Multiple comorbidities, such as obesity, diabetes, renal impairment and vascular/cardiac disease, may increase the risk of cellulitis treatment failure [22]. These conditions can cause lower extremity edema, masking signs and symptoms of cellulitis and leading to underestimation of the severity of the condition [22].

Management of wounds require attention if a patient shows clinical signs and symptoms of infection and becomes systemically unwell [23]. Wound infections require the combination of surgical debridement, antibiotic therapy and appropriate local wound care because an infection delays wound healing. Predisposing host factors for the development of post-surgical infections (e.g., diabetes, poor circulation, and immunosuppression) may overlap with those that might delay wound healing [24]. In these infections, the most likely causative pathogens include $S$. aureus, although Gram-negative bacteria may also cause infections [25]. Consideration of MRSA is necessary in countries with a high prevalence; for example, MRSA prevalence $\sim 50 \%$ is reported in Russia and Mexico and $12-30 \%$ in Singapore [26-29], although 
much lower rates are seen in most European countries [30].

Of note, the cases described in this case series were complex due to the presence of complicating factors such as SIRS, myositis, or even sepsis, a condition that is frequently excluded from ABSSSI Phase 3 trials because the increased associated morbidity and mortality may confound the assessment of antibiotic effectiveness $[15,16,31]$. Furthermore, patients with metal implants are normally expected to require a long course (up to 6-8 weeks) of antibiotic treatment [32]; therefore, such cases would not be included in Phase 3 trials. Complicating factors similar to these present in these four cases may allow inclusion into open-label, postapproval, Phase 4 studies.

Antibiotic selection for the empiric treatment of cellulitis and wound infections is challenging. For patients with an ABSSSI due to methicillin-susceptible $S$. aureus or streptococci, a beta-lactam, a tetracycline, or clindamycin would be recommended empirically as first-line therapy [23], which were selected as empiric therapies for our non-purulent cellulitis cases. However, a suspicion of MRSA as the cause of an ABSSSI is warranted when a patient fails on firstline beta-lactam therapy and/or any risk factor is present (e.g., high local prevalence, previous MRSA infection or colonization, previous hospitalization or surgery) such as in our cellulitis cases [33]. Furthermore, the culture results from exudate samples confirmed MRSA in our cases of wound infection. Guidelines recommend the use of vancomycin (plus piperacillin/tazobactam) for severe cases of non-necrotizing cellulitis [23] and for wound infection due to confirmed MRSA [23]. Vancomycin treatment can be problematic for obese or morbidly obese patients, like most of our patients, due to its dosing and exposure variability, and for those with renal disease, who are at an increased risk of adverse events due to elevated trough levels $[34,35]$. Of note, the risk of treatment failure during vancomycin treatment is increased when vancomycin MIC is reported as $\geq 1.5 \mu \mathrm{g}$ / $\mathrm{mL}$ (i.e., confirmed MRSA with elevated vancomycin MIC in Case 4) [36]. Daptomycin has a very high potency against Gram-positive ABSSSI/cSSSI pathogens. However, its use is not recommended in patients with elevated CK levels (as reported in Case 2) because it may further delay tissue repair in soft tissue infections [23, 35], or in cases with elevated vancomycin MIC (as reported in Case 4) due to potential cross-resistance with vancomycin $[37,38]$.

When a glycopeptide antibiotic seems unsuitable, linezolid is frequently used for the treatment of skin infections because it has high potency against most causative Gram-positive pathogens and has good skin and soft tissue penetration [39]. The dosing of linezolid in obese or morbidly obese [39] patients, and in patients with renal [40] or hepatic [41] impairment, has recently been queried. Thus, therapeutic monitoring for linezolid was recently recommended to maintain its trough levels between 2 and $8 \mathrm{mg} / \mathrm{mL}$ [39]. The most frequently associated adverse reactions with linezolid treatment are gastrointestinal (GI) side effects and thrombocytopenia [42]. These adverse events may emerge as early as within 10 days and, furthermore, the risk of thrombocytopenia is increased with prolonged duration $[15-17,43]$. These limiting factors were present in three of the four presented cases (Case 1: decreasing platelet count, Case 2: GI symptoms, Case 3: renal and hepatic impairment, and thromboprophylaxis with heparin), while in Case 4, the treating surgeon excluded this antibiotic due to an anticipated prolonged duration and an increased risk of thrombocytopenia, respectively.

Tedizolid phosphate was selected for the cases reported here because of its high in vitro potency against Gram-positive bacteria $[10,11,44]$, including MRSA and streptococci. It has a good penetration into skin and soft tissue [45], a very high oral bioavailability allowing equivalent dosing when switching from IV to PO therapy $[9,12,13]$, and convenient once-daily dosing $[8,9,12,13]$. In addition, unlike some antibiotics, such as vancomycin, daptomycin or ceftaroline, tedizolid phosphate does not require dose adjustment in special populations, including the elderly, the obese and morbidly obese, and patients with renal or hepatic impairment [14, 46-49]. In trials, tedizolid phosphate IV/PO 
once daily for 6 days demonstrated comparable efficacy to linezolid IV/PO twice daily for 10 days in patients with cellulitis, major cutaneous abscess and wound infection, and similar clinical cure rates were observed in subgroups of patients, including those with higher BMI or moderate/severe renal impairment and the elderly [15-17]. Furthermore, irrespective of the presence or absence of parameters related to infection severity (i.e., fever, SIRS, immature neutrophil count, severe pain, or elevated WBC count), high clinical success rates were achieved in patients treated with tedizolid phosphate [50]. All four patients reported in our case series responded to tedizolid therapy within $48-72 \mathrm{~h}$ with cessation of lesion spread, detectable reduction in erythema, lack of fever, reduction in pain and/or improvement of laboratory parameters. They had sustained improvement of signs and symptoms at the end of therapy and were considered to have achieved clinical cure at later follow-up.

In the severe ABSSSI cases reported here, physicians extended the duration of tedizolid phosphate therapy beyond 6 days (i.e. 714 days). For the patient with spinal fusion surgery and subsequent wound infection caused by MRSA (Case 4), antibiotic treatment was initially anticipated to take several weeks. As prolonged duration of linezolid therapy increases the risk of anemia or thrombocytopenia [42], an antibiotic with lower myelotoxicity is preferred for extended treatment durations. The objective was to cure the infection, and to prevent re-operation and removal of the metal instrument because re-operation is necessary in a large proportion of such patients due to MRSA infection [51]. Furthermore, surgical patients with renal impairment who require thromboprophylaxis with low-molecular weight heparin following surgery (Case 3) have an increased risk of heparin-induced thrombocytopenia and are ineligible for treatment with MRSA antibiotics documented to cause thrombocytopenia, such as linezolid [52-54]. Tedizolid phosphate $200 \mathrm{mg}$ once-daily administration is associated with a significantly lower risk of thrombocytopenia versus linezolid $600 \mathrm{mg}$ twice-daily administration for up to 21 days in healthy individuals [55], and in ABSSSI patients [56], another crucial factor that contributed to the antibiotic selection in patients with wound infections. Of note, no hematological (or other) side effects had been reported for these complex patients with tedizolid as documented by maintained normal levels of platelet count during and after treatment.

The duration of therapy is not usually decided at the time of antibiotic selection, instead it becomes clearer within $48-72 \mathrm{~h}$ [57]. For patients with cellulitis, the effective durations of IV therapy and total therapy are not well characterized [58, 59]. In general, IV therapy for 5-6 days is typical in clinical practice [58]. Within 2-3 days, patients may respond to antibiotic therapy with (1) a cessation of lesion spread, (2) an improvement of local inflammation, (3) a reduced leukocyte count, or (4) an improved CRP level [57], although, to achieve clinical response/improvement, antibiotic escalation may be necessary [57]. An analysis of patients treated with tedizolid phosphate or linezolid in the ESTABLISH studies suggested that the lack of clinical response (i.e., $<20 \%$ reduction in lesion size) to treatment within $48-72 \mathrm{~h}$ is not predictive of clinical failure at the post-treatment evaluation visit or test-of-cure visit [60]. In such complex cases as these reported here, the clinical assessment of the patients should be conducted at the later stage. In patients with wound infections, when MRSA is confirmed or is highly suspected due to the presence of risk factors (e.g., history of MRSA) when pathogen isolation is not feasible, tedizolid phosphate $200 \mathrm{mg}$ once daily for 6 or 7 days appears to be an appropriate treatment. Treatment duration can be extended at the discretion of the treating physician if sepsis, SIRS or other complications are present, or if there is a risk of relapse. In the series of severe ABSSSI cases reported here, tedizolid phosphate was efficacious and well tolerated when administered at an extended treatment duration of up to 14 days.

\section{CONCLUSION}

In conclusion, the good efficacy and safety profile of tedizolid phosphate seen in these 
cases, with a treatment duration extended up to 14 days (beyond the approved 6 days), make it a valuable treatment choice for patients with severe ABSSSIs, including complex cases with prior treatment failure or late-onset infections.

\section{ACKNOWLEDGEMENTS}

The authors thank the participants of the study.

Funding. No funding was provided to the authors for preparation of the manuscript. Funding for the publication charges was provided by Bayer AG, Berlin, Germany. All authors had full access to all of the data of patients in this case series and take complete responsibility for the integrity of the data and accuracy of the data analysis.

Editorial Assistance. Editorial assistance in the preparation of this manuscript was provided by Adrienn Kis, PhD, Highfield Communication, Oxford, United Kingdom. Support for this assistance was funded by Bayer AG, Berlin, Germany.

Authorship. All named authors meet the International Committee of Medical Journal Editors (ICMJE) criteria for authorship for this manuscript, take responsibility for the integrity of the work as a whole, and have given final approval to the version to be published.

Disclosures. Sergey Shlyapnikov has received consultancy fee or honorarium for participation in speaker's bureau from Astra Zeneca, Bayer, Biotest, Merck Sharp \& Dohme, Pfizer, Takeda, and Thermofisher. Arturo Jarugeui has received consultancy fees from Bayer. Nana N. Khachatryan has received consultancy fees from Bayer. Asok Kurup has received consultancy fees from Bayer. Javier de la CabadaBauche has received consultancy fees from Bayer. Hoe N. Leong has received consultancy fees from Bayer. $\mathrm{Li} \mathrm{Li}$ is employee of Bayer AG, Germany. Prof Mark H. Wilcox has received consulting fees from AiCuris, Astra-Zeneca, Bayer, Cerexa, Durata, The Medicines
Company, Menarini, Motif Biosciences, Nabriva, Paratek and Pfizer; lecture fees from Allergan, Astra-Zeneca and Pfizer; and Grant support from Pfizer.

Compliance with Ethics Guidelines. Informed consent was obtained by the treating physicians from each patient for being included in the publication.

Data Availability. Data sharing is not applicable to this article as no datasets were generated or analyzed during the current study.

Open Access. This article is distributed under the terms of the Creative Commons Attribution-NonCommercial 4.0 International License (http://creativecommons.org/licenses/ by-nc/4.0/), which permits any noncommercial use, distribution, and reproduction in any medium, provided you give appropriate credit to the original author(s) and the source, provide a link to the Creative Commons license, and indicate if changes were made.

\section{REFERENCES}

1. Pulido-Cejudo A, Guzmán-Gutierrez M, JalifeMontaño M, et al. Management of acute bacterial skin and skin structure infections with a focus on patients at high risk of treatment failure. Ther Adv Infect Dis. 2017;4(5):143-61.

2. Garg A, Lavian J, Lin G, Sison C, Oppenheim M, Koo B. Clinical characteristics associated with days to discharge among patients admitted with a primary diagnosis of lower limb cellulitis. J Am Acad Dermatol. 2017;76(4):626-31.

3. Peterson RA, Polgreen LA, Cavanaugh JE, Polgreen PM. Increasing incidence, cost, and seasonality in patients hospitalized for cellulitis. Open Forum Infect Dis. 2017;4(1):ofx008.

4. Lee AS, Levell NJ. Dermatology-led lower-limb cellulitis service: analysis of 1579 referrals (2007-15). Br J Dermatol. 2017;177(2):596-7.

5. Sutherland M, Parent A. Diagnosis and management of cellulitis: a dermatology perspective. $\mathrm{Br} \mathrm{J}$ Comm Nurs. 2017;22(6):272-5. 
6. Konychev A, Heep M, Moritz RK, et al. Safety and efficacy of daptomycin as first-line treatment for complicated skin and soft tissue infections in elderly patients: an open-label, multicentre, randomized phase IIIb trial. Drugs Aging. 2013;30(10):829-36.

7. Suaya JA, Eisenberg DF, Fang C, Miller LG. Skin and soft tissue infections and associated complications among commercially insured patients aged 0-64 years with and without diabetes in the US. PLoS ONE. 2013;8(4):e60057.

8. Flanagan SD, Bien PA, Muñoz KA, Minassian SL, Prokocimer PG. Pharmacokinetics of tedizolid following oral administration: single and multiple dose, effect of food, and comparison of two solid forms of the prodrug. Pharmacotherapy. $2014 ; 34(3): 240-50$.

9. Flanagan S, Fang E, Muñoz KA, Minassian SL, Prokocimer PG. Single- and multiple-dose pharmacokinetics and absolute bioavailability of tedizolid. Pharmacotherapy. 2014;34(9):891-900.

10. Pfaller MA, Flamm RK, Jones RN, Farrell DJ, Mendes RE. Activities of tedizolid and linezolid determined by the reference broth microdilution method against 3032 Gram-positive bacterial isolates collected in Asia-Pacific, Eastern Europe, and Latin American countries in 2014. Antimicrob Agents Chemother. 2016;60(9):5393-9.

11. Bensaci M, Sahm D. Surveillance of tedizolid activity and resistance: in vitro susceptibility of Grampositive pathogens collected over 5 years from the United States and Europe. Diagn Microbiol Infect Dis. 2017;87(2):133-8.

12. Chen R, Shen K, Chang X, Tanaka T, Li L, Hu P. Pharmacokinetics and safety of tedizolid after single and multiple intravenous/oral sequential administrations in healthy Chinese subjects. Clin Ther. 2016;38(8):1869-79.

13. Kim Y, Kim A, Lee S, et al. Pharmacokinetics, safety, and tolerability of tedizolid phosphate after singledose administration in healthy Korean male subjects. Clin Ther. 2017;39(9):1849-57.

14. Sivextro ${ }^{\circledR}$ (tedizolid phosphate). Prescribing information. Whitehouse Station, NJ, USA: Merck \& Co; 2017.

15. Prokocimer P, De Anda C, Fang E, Mehra P, Das A. Tedizolid phosphate vs linezolid for treatment of acute bacterial skin and skin structure infections: the ESTABLISH-1 randomized trial. JAMA. 2013;309(6):559-69.

16. Moran GJ, Fang E, Corey GR, Das AF, De Anda C, Prokocimer P. Tedizolid for 6 days versus linezolid for 10 days for acute bacterial skin and skin-structure infections (ESTABLISH-2): a randomised, double-blind, phase 3, non-inferiority trial. Lancet Infect Dis. 2014;14(8):696-705.

17. Shorr AF, Lodise TP, Corey GR, et al. Analysis of the phase 3 ESTABLISH trials of tedizolid versus linezolid in acute bacterial skin and skin structure infections. Antimicrob Agents Chemother. 2015;59(2):864-71.

18. Sivextro ${ }^{\circledR}$ (tedizolid phosphate). Prescribing information. Mexico: Bayer; 2016.

19. Sivextro ${ }^{\circledR}$ (tedizolid phosphate). Prescribing information. Singapore: Bayer; 2016.

20. Sivextro ${ }^{\circledR}$ (tedizolid phosphate). Summary of product characteristics. Russia: Bayer; 2016.

21. Linder KA, Malani PN. Cellulitis. JAMA. 2017;317(20):2142.

22. Conway EL, Sellick JA, Kurtzhalts K, Mergenhagen KA. Obesity and heart failure as predictors of failure in outpatient skin and soft tissue infections. Antimicrob Agents Chemother. 2017;61(3):e02389-416.

23. Stevens DL, Bisno AL, Chambers HF, et al. Practice guidelines for the diagnosis and management of skin and soft tissue infections: 2014 update by the Infectious Diseases Society of America. Clin Infect Dis. 2014;59(2):e10-52.

24. Anderson K, Hamm RL. Factors that impair wound healing. J Am Coll Clin Wound Spec. 2014;4(4):84-91.

25. Flamm RK, Sader HS, Jones RN. Ceftaroline activity tested against contemporary Latin American bacterial pathogens (2011). Braz J Infect Dis. 2014;18(2):187-95.

26. Sader HS, Farrell DJ, Flamm RK, Jones RN. Analysis of 5-year trends in daptomycin activity tested against Staphylococcus aureus and enterococci from European and US hospitals (2009-2013). J Glob Antimicrob Resist. 2015;3(3):161-5.

27. Sader HS, Castanheira M, Farrell DJ, Flamm RK, Mendes RE, Jones RN. Tigecycline antimicrobial activity tested against clinical bacteria from Latin American medical centres: results from SENTRY Antimicrobial Surveillance Program (2011-2014). Int J Antimicrob Agents. 2016;48(2):144-50.

28. Wijaya L, Hsu LY. Community-associated methicillin-resistant Staphylococcus aureus skin and soft tissue infections. Proc Singapore Healthc. 2010;19:212-9. 
29. Chow A, Lim VW, Khan A, et al. MRSA transmission dynamics among interconnected acute, intermediate-term, and long-term healthcare facilities in Singapore. Clin Infect Dis. 2017;64(Suppl 2):S76-81.

30. ECDC. Antimicrobial resistance surveillance in Europe 2015. https://ecdc.europa.eu/en/publicationsdata/antimicrobial-resistance-surveillance-europe2015. Accessed July 142017.

31. Itani KM, Shorr AF. FDA guidance for ABSSSI trials: implications for conducting and interpreting clinical trials. Clin Infect Dis. 2014;58(Suppl 1):S4-9.

32. Kasliwal MK, Tan LA, Traynelis VC. Infection with spinal instrumentation: review of pathogenesis, diagnosis, prevention, and management. Surg Neurol Int. 2013;4(Suppl 5):S392-403.

33. Stenstrom R, Grafstein E, Romney M, et al. Prevalence of and risk factors for methicillin-resistant Staphylococcus aureus skin and soft tissue infection in a Canadian emergency department. CJEM. 2009;11(5):430-8.

34. Rybak M, Lomaestro B, Rotschafer JC, et al. Therapeutic monitoring of vancomycin in adult patients: a consensus review of the American Society of Health-System Pharmacists, the Infectious Diseases Society of America, and the Society of Infectious Diseases Pharmacists. Am J Health Syst Pharm. 2009;66:82-98.

35. Bassetti M, Righi E. Safety profiles of old and new antimicrobials for the treatment of MRSA infections. Expert Opin Drug Saf. 2016;15(4):467-81.

36. van Hal SJ, Lodise TP, Paterson DL. The clinical significance of vancomycin minimum inhibitory concentration in Staphylococcus aureus infections: a systematic review and meta-analysis. Clin Infect Dis. 2012;54(6):755-71.

37. Fujimura S, Nakano Y, Watanabe A. A correlation between reduced susceptibilities to vancomycin and daptomycin among the MRSA isolates selected in mutant selection window of both vancomycin and daptomycin. J Infect Chemother. 2014;20:752-6.

38. Cui L, Tominaga E, Neoh HM, Hiramatsu K. Correlation between reduced daptomycin susceptibility and vancomycin resistance in vancomycin-intermediate Staphylococcus aureus. Antimicrob Agents Chemother. 2006;50(3):1079-82.

39. Roger C, Roberts JA, Muller L. Clinical pharmacokinetics and pharmacodynamics of oxazolidinones. Clin Pharmacokinet. 2018;57(5):559-75.
40. Matsumoto K, Takeshita A, Ikawa K, et al. Higher linezolid exposure and higher frequency of thrombocytopenia in patients with renal dysfunction. Int J Antimicrob Agents. 2010;36(2):179-81.

41. Ikuta S, Tanimura K, Yasui C, et al. Chronic liver disease increases the risk of linezolid-related thrombocytopenia in methicillin-resistant Staphylococcus aureus-infected patients after digestive surgery. J Infect Chemother. 2011;17(3):388-91.

42. Zyvox ${ }^{\circledR}$ (linezolid). Prescribing information. New York, NY, USA: Pfizer; 2015.

43. Tsuji Y, Hiraki Y, Matsumoto K, et al. Thrombocytopenia and anemia caused by a persistent high linezolid concentration in patients with renal dysfunction. J Infect Chemother. 2011;17(1):70-5.

44. Biedenbach DJ, Bouchillon SK, Johnson B, Alder J, Sahm DF. In vitro activity of tedizolid against Staphylococcus aureus and Streptococcus pneumoniae collected in 2013 and 2014 from sites in Latin American countries, Australia, New Zealand, and China. Eur J Clin Microbiol Infect Dis. 2016;35(12):1933-9.

45. Sahre M, Sabarinath S, Grant M, et al. Skin and soft tissue concentrations of tedizolid (formerly torezolid), a novel oxazolidinone, following a single oral dose in healthy volunteers. Int J Antimicrob Agents. 2012;40(1):51-4.

46. Flanagan S, Minassian SL, Morris D, Ponnuraj R, Marbury TC, Alcorn HW, Fang E, Prokocimer P. Pharmacokinetics of tedizolid in subjects with renal or hepatic impairment. Antimicrob Agents Chemother. 2014;58(11):6471-6.

47. Pai P. Pharmacokinetics of tedizolid in morbidly obese and covariate-matched nonobese adults. Antimicrob Agents Chemother. 2016;60(8):4585-9.

48. Flanagan S, Minassian SL, Passarell JA, Fiedler-Kelly J, Prokocimer P. Pharmacokinetics of tedizolid in obese and nonobese subjects. J Clin Pharmacol. 2017;57(10):1290-4.

49. Flanagan SD, Minassian SL, Prokocimer P. Pharmacokinetics, safety, and tolerability of tedizolid phosphate in elderly subjects. Clin Pharmacol Drug Dev. 2018. https://doi.org/10.1002/cpdd.426 (Epub ahead of print).

50. Sandison T, De Anda C, Fang E, Das AF, Prokocimer $P$. Clinical response of tedizolid versus linezolid in acute bacterial skin and skin structure infections by severity measure using a pooled analysis from two phase 3 double-blind trials. Antimicrob Agents Chemother. 2017;61(5):e02687-16. 
51. Patel H, Khoury H, Girgenti D, Welner S, Yu H. Burden of surgical site infections associated with select spine operations and involvement of Staphylococcus aureus. Surg Infect. 2017;18(4):461-73.

52. Cohen RA, Castellano M, Garcia CA. Heparin induced thrombocytopenia: case presentation and review. J Clin Med Res. 2012;4(1):68-72.

53. Salter BS, Weiner MM, Trinh MA, et al. Heparininduced thrombocytopenia: a comprehensive clinical review. J Am Coll Cardiol. 2016;67(21):2519-32.

54. Rondina MT, Walker A, Pendleton RC. Drug-induced thrombocytopenia for the hospitalist physician with a focus on heparin-induced thrombocytopenia. Hosp Pract (1995). 2010;38(2):19-28.

55. Lodise TP, Bidell MR, Flanagan SD, Zasowski EJ, Minassian SL, Prokocimer P. Characterization of the haematological profile of 21 days of tedizolid in healthy subjects. J Antimicrob Chemother. 2016;71(9):2553-8.

56. Lodise TP, Fang E, Minassian SL, Prokocimer PG. Platelet profile in patients with acute bacterial skin and skin structure infections receiving tedizolid or linezolid: findings from the Phase 3 ESTABLISH clinical trials. Antimicrob Agents Chemother. 2014;58:7198-204.

57. Bruun T, Oppegaard O, Hufthammer KO, Langeland N, Skrede S. Early response in cellulitis: a prospective study of dynamics and predictors. Clin Infect Dis. 2016;63(8):1034-41.

58. Friedman DN, Pollard J, Huffman S, et al. Randomized controlled trial of short course intravenous therapy for cellulitis and erysipelas of the lower limb (Switch): study protocol and pilot trial results. J Clin Trials. 2014;4:200. https://doi.org/10. 4172/2167-0870.1000200.

59. Jenkins TC, Knepper BC, Moore SJ, et al. Antibiotic prescribing practices in a multicenter cohort of patients hospitalized for acute bacterial skin and skin structure infection. Infect Control Hosp Epidemiol. 2014;35(10):1241-50.

60. Nathwani D, Corey R, Das AF, Sandison T, De Anda C, Prokocimer P. Early clinical response as a predictor of late treatment success in patients with acute bacterial skin and skin structure infections: retrospective analysis of 2 randomized controlled trials. Clin Infect Dis. 2017;64:214-7. 